\title{
An Example to Emulate: The Elizabeth McAlmont Trust Association for Care of the Countryside
}

Concern for the local environment is a widespread feature of life in Southern England today. Membership of conservation NGOs is high, bottles and newspapers are recycled, and opposition groups form quickly when wildlife habitat or areas of outstanding natural beauty are threatened; but most people feel there is little they can do to halt the small though all-too-frequent depredations that threaten the future of the countryside and its flora and fauna. Yet Mrs Kathleen McAlmont, a retired Surrey village schoolmistress, has shown that persistence and determination can achieve results against considerable odds.

About ten years ago she began to notice disturbing changes in a steep stand of 'ancient woodland' to the south of her house. The woods had been presented to the Church by King Henry VIII in the 16th century, but the land on the plateau above was privately owned and had recently been sold for new housing. Deciding that their view would be enhanced by the removal of trees, residents began felling first on their own land and then, without permission, on the church-owned woodland. The results were predictable. The land began to erode. Rain-water ran unchecked down the partially deforested slopes and flooded the farmland fields and cottages below. Aware of the likely long-term consequences if no action were taken, Mrs McAlmont started to write letters and make telephone calls to the Diocesan and local Government authorities. Her warnings met, initially, with little interest, even with apathy; but she persisted, and eventually induced those responsible to place a 'Blanket Tree Preservation Order' on the entire woodland.

This experience made her aware of the need for constant vigilance if major local detrimental changes were to be prevented. In 1983 she formed 'The Elizabeth McAlmont* Memorial Trust Association for the Care of the Countryside'. The Trust was nominated as the agent for the ancient woodland, and was given responsibility for the planting and care of new trees and the general upkeep of the woods. Its other duties include the maintenance of hedgerows and public rights-of-way in the area, and the "education of young people in the practice and science of arboriculture and dendrology'. For the latter purpose a 'Young Foresters' section was formed and a small group of children meets on alternate Saturdays to help with the practical work of the Trust and learn to identify the trees, other plants, and animal wildlife which it encounters.

Many of the Trust's members enjoy the opportunity to take part in outdoor work. Others contribute by typing, book-keeping, donating funds, or giving professional advice. Some projects are undertaken in liaison with local members of national environmental organizations such as the British Trust for Conservation Volunteers and the British Wildlife Trust.

\section{Some Projects Continued or Started in 1990-91}

The Common:- Since the end of World War II there has been little grazing on the village's thirty acres $(c .12$ ha) of common land and so on it a de facto Nature reserve has evolved. Apparently under the impression that they were performing a public service, new residents were regularly mowing the common in front of their houses,

* Named after her younger daughter, who had died at the age of 25 in Singapore. despite requests that they should desist. (In a particularly wanton act of vandalism a stand of flowering Bluebells (Endymion nonscriptus) was mown down last spring.) Since direct approach to those responsible proved ineffective, Mrs McAlmont organized a campaign of letter-writing to the Borough Council, requesting that the common be officially declared a Nature reserve. A public meeting, attended by County and Borough Councillors and the area Manager of Parks and Open Spaces, was held and the unauthorized mowers have now received letters from the Borough Council informing them that it is illegal to cut or damage any of the plant life on the common.

The Copse:- A corner of pasture-land which had been allowed to degenerate into an unsightly dump of old tyres, concrete blocks, and general debris, has been transformed into a small wooded copse/Nature reserve. Over sixty tons of rubbish were removed by volunteers, and native trees and a perimeter hedge of Dog Rose (Rosa canina agg.) and Blackthorn (Prunus spinosa) were planted. At the end of their first year most of the trees are thriving, wild flowers have 'returned', and several species of butterfly have been identified.

Planting on Road-verges:- Following a major roadimprovement scheme in the locality, the Trust obtained permission from the national Department of Transport to plant the barren roadside verges with wild flowers. Soil samples were taken and analysed, and an appropriate sand-and-seed mix was prepared and used. A large contingent of volunteers undertook the planting in early spring and the results during this past summer have been spectacular.

Revitalizing the Pond:- A small pond on the edge of the common had silted up almost to the point of disappearance. Study of old maps and some exploration on foot revealed that its feeder stream had been diverted for agricultural use. Permission was obtained to reopen the original watercourse, and volunteers have now cleared the old stream-bed of shrubs, stinging-nettles (Urtice dioica), and rubbish. A mechanical digger has been used to excavate the pond, and a civil engineer has prepared a plan of precise levels to be dug by hand along the watercourse. Work is still in progress and it is hoped that, before long, water will return permanently to the pond so that it can again offer habitats for much aquatic and semi-aquatic wildlife, thus introducing a new range of interests for young and old alike.

\section{Widening Beneficial Influence}

The Trust has over 250 members and Mrs McAlmont remains its Chairman. She is Chief Planning Officer for her Parish Council but is consulted on tree-planting projects, appeals against planning applications, and various other countryside concerns, over a much wider area. Despite its proximity to the capital, and the constant demand for housing and commercial development, Surrey remains the most heavily-wooded county in England,* and her efforts to save individual trees or small areas of woodland frequently meet with incomprehension, apathy,

* Confirmed to the Author by the British Forestry Commission. $-\mathrm{Ed}$. 
derision, and even personal abuse. But despite indifferent health, she continues her work with determination.

The British Trust for Conservation Volunteers lists nearly thirty small, independent conservation groups in the county of Surrey alone. Not all run a continuous programme in the manner of the McAlmont Trust but, taken together, they probably represent the best hope for the
English countryside in its continuous battle against official neglect and ill-planned development.

CHRISTINE MARSH
l43 Peperharow Road
Godalming
Surrey GU7 $2 P W$
England, $U K$.

\section{The Social Origins and Impact of Deforestation in Central America}

The United Nations Research Institute for Social Development (UNRISD) has recently released a Discussion Paper entitled The Social Origins and Impact of Deforestation in Central America, by Peter Utting. The paper, based on research conducted during the late 1980s, describes the principal processes underlying deforestation in the region, the ways in which deforestation has affected the livelihood systems of different social groups, and individual and collective responses to those changes. The Author highlights the role played by government policies and land-tenure systems in deforestation processes, and examines the ways in which contemporary phenomena such as militarization, agrarian reform, and economic stabilization and adjustment, have affected deforestation.

The experience of forest protection initiatives in the region is also discussed, along with a brief assessment of some of their strengths and weaknesses from the point of view of contributing to environmental rehabilitation and social development. The Author concludes by outlining the content of a second phase of research, consisting of case-studies in Guatemala, Costa Rica, Nicaragua, and Honduras, which will shed further light on aspects associated with the social impact of deforestation and the effectiveness of different types of forest protection initiatives in promoting sustainable development.

The Discussion paper is part of the UNRISD research programme on the Social Dynamics of Deforestation in Developing Countries. The programme is concerned with the national and regional implications of deforestation for the livelihood and living conditions of poverty groups in rural and urban areas. Pertinent research is currently being carried out in Brazil, Central America, Nepal, and Tanzania, along with thematic studies on related issues.

The above research programme is being undertaken in coordination with UNRISD's ongoing work on Environment, Sustainable Development, and Social Change. Other programmes in this field include those of Sustainable Development through People's Participation in Resource Management; Women, Environment, and Social Change; Population Dynamics, Environmental Change, and Development; and the UNRISD Conference on Socioeconomic Dimensions of the Environmental Debate.

UNRISD was established nearly thirty years ago to promote research on the most pressing social issues of development. Multidisciplinary studies are carried out in collaboration with the Institute's extensive network of scholars and research institutes. Conferences are held in conjunction with research programmes, and there is active publication of research reports, discussion papers, and books. Inquiries about UNRISD research programmes and/or available publications should be addressed to: Reference Centre, United Nations Research Institute for Social Development, Palais des Nations, CH-1211 Geneva 10, Switzerland.

ADRIENNE CRUZ
UN Research Institute for Social Development
Palais des Nations
CH-1211 Geneva 10
Switzerland.

ADRIENNE CRUZ Palais des Nations Switzerland.

\section{Environment Protection Campaign in Southern India}

Environmental problems in India arise particularly from the ever-growing human and domestic-animal populations which are making increasing demands on natural resources. The result is the over-exploitation of the environment and its consequent degradation.

\section{Long-felt Need}

In India over $80 \%$ of the people live in villages. These villagers contribute a great deal to the degradation of the environment - by cutting the trees for firewood, by polluting the atmosphere with wastes, and by living in unhygienic conditions. Consequently we thought of tackling this problem at the grassroots level, aspiring to turn these people into agents of environmental protection.

The present-day environmental awareness programmes - using books, films, newspapers, magazines, electronic media, television, etc. - throughout the world have chiefly reached the wealthier and better-educated segments of the urban population. The vast majority of rural masses have been untouched by these campaigns. With a view to educating and training the rural people - especially women, agricultural labourers, and coolie workers - the Development Wing of SHEPHERD (a social extension and people's development unit) has spread the message of environmental protection and conservation from 1988 onwards.

\section{Awareness and Training}

As the village headman and the village development association are the most influential factors in any Indian village, we first gave a training programme on environmental protection to these people, and when once they had become convinced of our message, we were able to have wider influence and believe we have reached some 50,000 people in the last few years. We used a variety of teaching aids, including folk arts, puppetry, and street plays. The training is of three days' duration, and there is a follow-up every month to check that the trained people are following what they learnt during training sessions and to determine whether they take care to protect the trees and really do all they can to prevent pollution.

As a result of our training, villagers started forming Nature Clubs which act as the environment protecting and monitoring force in each village. The Nature Clubs raise seedlings in nurseries and distribute saplings to people. They also look after the cleanliness of the village. It is heartening to note that many of the villages which used to be barren when we began our work, can now boast of 